\title{
Temporal consistency of lidar observations during aerosol transport events in the framework of the ChArMEx/ADRIMED campaign at Minorca in June 2013
}

\author{
Patrick Chazette $^{1}$, Julien Totems ${ }^{1}$, Gérard Ancellet ${ }^{2}$, Jacques Pelon ${ }^{2}$, and Michaël Sicard ${ }^{3}$ \\ ${ }^{1}$ LSCE, CEA-CNRS-UVSQ, UMR 8212, Gif-sur-Yvette, France \\ ${ }^{2}$ Sorbonne Universités, UPMC Université Paris 06, CNRS-UVSQ, UMR 8190 LATMOS, Paris, France \\ ${ }^{3}$ RSLab/IEEC-CRAE, Universitat Politècnica de Catalunya, Barcelona, Spain
}

Correspondence to: Patrick Chazette (patrick.chazette@1sce.ipsl.fr)

Received: 9 October 2015 - Published in Atmos. Chem. Phys. Discuss.: 19 November 2015

Revised: 15 February 2016 - Accepted: 16 February 2016 - Published: 4 March 2016

\begin{abstract}
We performed synergetic daytime and nighttime active and passive remote-sensing observations at Minorca (Balearic Islands, Spain), over more than 3 weeks during the Chemistry-Aerosol Mediterranean Experiment/Aerosol Direct Radiative Effect in the Mediterranean (ChArMEx/ADRIMED) special observation period (SOP 1a, June-July 2013). We characterized the aerosol optical properties and type in the low and middle troposphere using an automated procedure combining Rayleigh-Mie-Raman lidar $(355,387$ and $407 \mathrm{~nm})$ with depolarization $(355 \mathrm{~nm})$ and AERONET Cimel ${ }^{\circledR}$ sun-photometer data. Results show a high variability due to varying dynamical forcing. The mean column-averaged lidar backscatter-to-extinction ratio (BER) was close to $0.024 \mathrm{sr}^{-1}$ (lidar ratio of $\sim 41.7 \mathrm{sr}$ ), with a large dispersion of $\pm 33 \%$ over the whole observation period due to changing atmospheric transport regimes and aerosol sources. The ground-based remote-sensing measurements, coupled with satellite observations, allowed the documentation of (i) dust particles up to $5 \mathrm{~km}$ (above sea level) in altitude originating from Morocco and Algeria from 15 to 18 June with a peak in aerosol optical thickness (AOT) of $0.25 \pm 0.05$ at $355 \mathrm{~nm}$, (ii) a long-range transport of biomass burning aerosol (AOT $=0.18 \pm 0.16)$ related to North American forest fires detected from 26 to 28 June 2013 by the lidar between 2 and $7 \mathrm{~km}$ and (iii) mixture of local sources including marine aerosol particles and pollution from Spain. During the biomass burning event, the high value of the particle depolarization ratio $(8-14 \%)$ may imply the presence of dust-like particles mixed with the biomass burning aerosols in the mid-troposphere. For the
\end{abstract}

field campaign period, we also show linearity with SEVIRI retrievals of the aerosol optical thickness despite $35 \%$ relative bias, which is discussed as a function of aerosol type.

\section{Introduction}

The Mediterranean has been identified as one of the "hotspots" in projections of future climate change (Giorgi and Lionello, 2008), and it has been recently shown that aerosol direct and semi-direct effects, which were not properly taken into account in global climate change simulations (IPCC, 2014), have a significant impact on surface temperature, evaporation, and precipitation at the regional scale (Nabat et al., 2015), i.e. a likely positive feedback on the trend for future dryer and thus more turbid Mediterranean summers. Due to the variability of aerosol properties over the Mediterranean basin, this calls for a more representative description of aerosol optical properties and spatiotemporal distribution by both observations and models.

Regional experiments including measurements of the vertical distribution of aerosols were performed some time ago to characterize aerosols around the Mediterranean Sea: (i) in the framework of the MEditerranean DUSt Experiment (MEDUSE) in 1997 (Hamonou et al., 1999), (ii) in the Scientific Training and Access to Aircraft for Atmospheric Research Throughout Europe (STAAARTE) airborne flights in 1997 (Dulac and Chazette, 2003) and 1998 (Formenti et al., 
2002), (iii) with a lidar deployed in Crete (Gobbi et al., 2000) or an instrumented ultralight aircraft in Lampedusa (Di Iorio et al., 2003) during the Photochemical Activity and U1traviolet Radiation (PAUR II) campaign in 1999, (iv) over the eastern Mediterranean basin during the Mediterranean Intensive Oxidant Study (MINOS; Lelieveld et al., 2002) and Mediterranean Israeli Dust Experiment (MEIDEX; Levin et al., 2005) in 2001, and (v) over the urban and industrial region of Marseille-Fos-Berre on the French Mediterranean coast also in 2001 (Cros et al., 2004; Cachier et al., 2005); and (vi) in the framework of the EARLINET network (Papayannis et al., 2008). Such past experiments have produced very useful information about the vertical distribution of Mediterranean aerosol optical properties, based on in situ observations and lidar measurements. During those preceding campaigns in the Mediterranean region, the use of aerosol lidars was focused on rather short time periods, but they appear as a very powerful tool to identify the wide spectrum of aerosol types encountered in the tropospheric column (e.g. Chazette, 2003; Chazette et al., 2005a; Berthier et al., 2006; Groß et al., 2011; Tesche et al., 2011; Nisantzi et al., 2014). The multidisciplinary programme Mediterranean Integrated Studies at the Regional and Local Scales (MISTRALS; http: //www.mistrals-home.org), initiated by CNRS/INSU in 2010 to study the future habitability of the Mediterranean region, offered the opportunity, within the Chemistry-Aerosol Mediterranean Experiment (ChArMEx, http://charmex.lsce. ipsl.fr), to conduct ground-based and airborne lidar observations at the scale of the western Mediterranean basin.

The ChArMEx/Aerosol Direct Radiative Effect in the Mediterranean (ADRIMED) special observation period (SOP-1a) was set up from 11 June to 3 July to study aerosol optical properties and radiative effects in the western Mediterranean during the dry season, which shows a maximum in aerosol optical depth (Nabat et al., 2013). The campaign involved several surface stations throughout the western Mediterranean, research aircrafts, and instrumented balloons (Mallet et al., 2016). In this work, we focus on both active and passive remote-sensing observations performed at Minorca (Balearic Islands, Spain) during this campaign. The main goal of the paper is to demonstrate the benefit of continuous daytime and nighttime lidar measurements during at least 3 weeks to derive aerosol optical properties. It improves both the assessment of the diurnal variation of the aerosol distribution related to the planetary boundary layer (PBL) growth and the probability of detecting long-range transports of aerosol plumes. In Sect. 2, we first present the experimental set-up. Retrieved aerosol optical properties for both nighttime and daytime conditions are analysed in Sect. 3 to give an overall identification of aerosol types. In Sect. 4, we discuss the different origins of aerosol particles before discussing comparison with the Spinning Enhanced Visible and InfraRed Imager (SEVIRI) retrievals and concluding in Sect. 5.

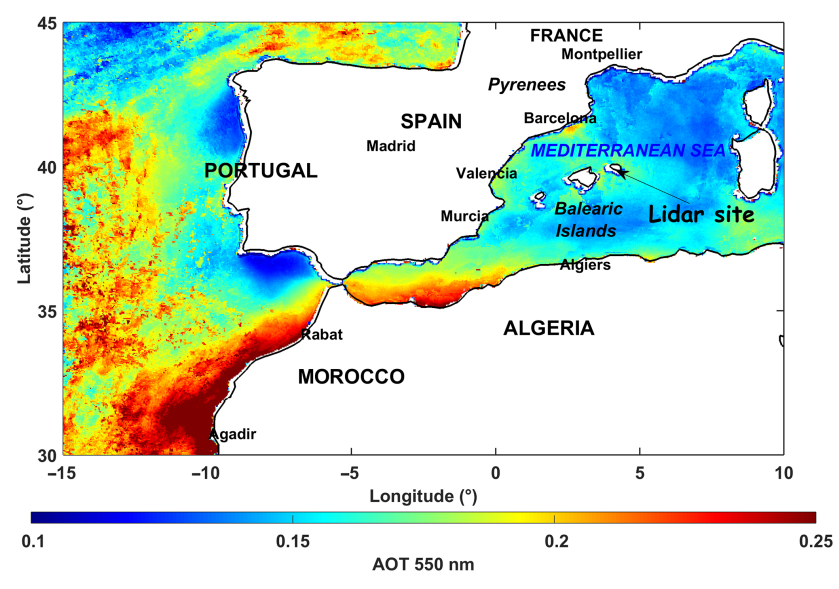

Figure 1. Location of the Cap d'en Font surface station on Minorca, on a map of the MSG/SEVIRI-derived aerosol optical thickness at $550 \mathrm{~nm}$ over ocean, averaged over the campaign period (10 June3 July 2013, daytime).

\section{Ground-based remote-sensing measurements}

During the campaign, our custom-made Raman lidar WALI (Chazette et al., 2014) was operated together with an AERONET sun photometer at Cap d'en Font (http://aeronet. gsfc.nasa.gov/new_web/photo_db/Cap_d_En_Font.html) on the south-eastern coast of Minorca (Balearic Islands, Spain). The instruments were located within $\sim 6 \mathrm{~m}$ from each other, at $39^{\circ} 49^{\prime} 32.9^{\prime \prime} \mathrm{N}, 04^{\circ} 12^{\prime} 29.3^{\prime \prime} \mathrm{E}$, at $\sim 10 \mathrm{~m}$ above the mean sea level (a.m.s.l.) and less than $70 \mathrm{~m}$ from a small cliff on the sea shore. The choice to use only remote-sensing instruments is driven by the lack of representativeness of the ground-based in situ measurements, which are mainly affected by local dynamical forcings. This is especially true in coastal regions (Chazette, 2003). The selected location is mainly affected by Saharan and Spanish air masses. Figure 1 shows the location of the station approximately in the centre of the western Mediterranean basin. The campaign average aerosol optical thickness $\left(\mathrm{AOT}_{550}\right.$, at $550 \mathrm{~nm}$ ) distribution derived from SEVIRI on board the geostationary Meteosat Second Generation (MSG) platform is reported in this figure. It shows a classical north-south decreasing gradient in the western Mediterranean basin due to African dust with maximum values between 0.20 and 0.25 in the Alboran Sea, and minimum values of $\sim 0.12$ in the Gulf of Lion. Intermediate values of $\sim 0.17$ are found around Minorca.

\subsection{Raman lidar}

The WALI instrument uses an emitted wavelength of $354.7 \mathrm{~nm}$ and is designed to fulfil eye-safety conditions. The instrument, its calibration and the associated errors are documented in Chazette et al. (2014) and will not be detailed here. During all the experiment, the acquisition was performed continuously with a vertical resolution of $15 \mathrm{~m}$ for mean pro- 
(a)

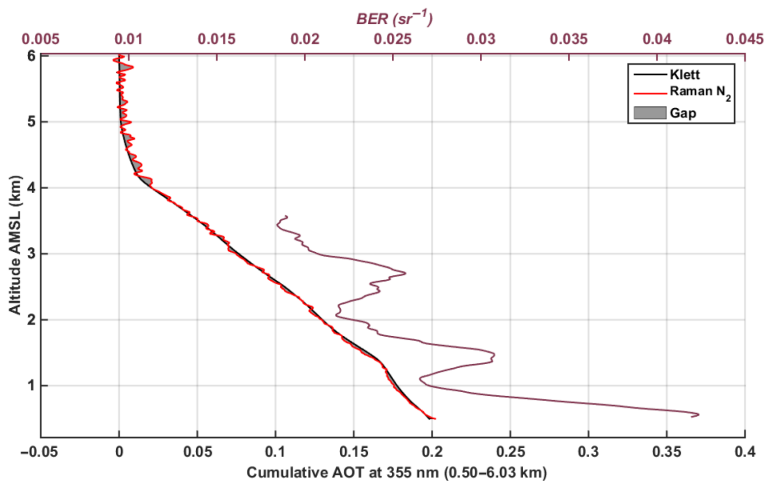

(b)

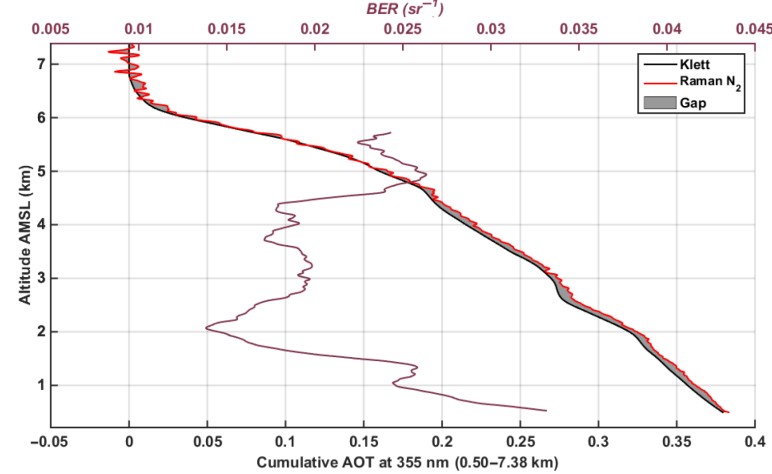

Figure 2. Result of the lidar inversion on the both the integrated AOT and the BER for the elastic (Klett, 1985, algorithm) and $\mathrm{N}_{2}-$ Raman channels: (a) the nights of 16-17 June, and (b) the nights of 27-28 June. The grey area highlights the gap between the two approaches.

files of 1000 laser shots leading to a temporal sampling close to $1 \mathrm{~min}$. The presence of clouds was visually detected in the lidar time series of range-corrected lidar backscattered profile, and the corresponding periods were removed. Two validated (e.g. Dieudonné et al., 2015) measurement synergy types have been used to retrieve the aerosol optical properties from the lidar. During daytime the sun-photometer $\mathrm{AOT}_{355}$ is considered as a constraint for the lidar inversion as in Chazette (2003). Note that using the total AOT only allows us to retrieve a column-averaged or equivalent backscatterto-extinction ratio (BER, product of the backscatter phase function and the single scattering albedo, inverse of the lidar ratio LR), integrating all the aerosol layers. During nighttime, the two elastic and the $\mathrm{N}_{2}$-Raman channels of the lidar are used to determine simultaneously the aerosol BER, the vertical profile of the aerosol extinction coefficient $\left(\alpha_{\mathrm{e}}\right)$, and the linear particle depolarization ratio (PDR). All methodological details are well presented in Royer et al. (2011) and Chazette et al. (2012a, 2014). The relative uncertainty on the BER is $\sim 5 \%$ during nighttime ( $\sim 10 \%$ during daytime). The relative uncertainties on the PDR are close to $10 \%$ for the encountered AOT at $355 \mathrm{~nm}\left(\mathrm{AOT}_{355}>0.2\right)$. The relative uncertainty on the AOT is less than $2 \%$. The relative uncer- tainty on the water vapour mixing ratio (WVMR) is between 7 and $11 \%$ within the first kilometres of the atmosphere.

Two representative examples of AOT and BER retrieval are given in Fig. 2 corresponding to the main aerosol sources, biomass burning and desert dust observed during this campaign. They demonstrate the good agreement between the cumulative AOT derived from the $\mathrm{N}_{2}-$ Raman and the elastic channels. The calculations have been performed using the average profile of nighttime measurements during the nights of 16-17 and 27-28 June, for biomass and dust cases, respectively. To improve the inversion, the mean profiles have been inverted using an altitude-variable BER and a regularization approach (Royer et al., 2011). For the first example, the BER (LR) is close to $0.04 \mathrm{sr}^{-1}(25 \mathrm{sr})$ in the marine boundary layer (MBL) and decreases with the altitude to reach values between 0.02 and $0.025 \mathrm{sr}^{-1}$ (50 and $40 \mathrm{sr}$ ) between 2 and $3 \mathrm{~km}$ a.m.s.l. The values of BER are similar for the second example in the MBL, but after decreasing below $0.02 \mathrm{sr}^{-1}$ in the aerosol layer above the MBL, they significantly increase above $4 \mathrm{~km}$ a.m.s.l. to reach $\sim 0.025 \mathrm{sr}^{-1}$. These two profiles correspond to the main contributions of aerosol sources encountered during this period: maritime aerosol in the MBL (BER $\sim 0.04 \mathrm{sr}^{-1}$ or LR $\sim 25 \mathrm{sr}$ ), dust (BER $\sim 0.025 \mathrm{sr}^{-1}$ or $\mathrm{LR} \sim 40 \mathrm{sr}$ ) and biomass burning or local pollution $\left(\mathrm{BER}<0.02 \mathrm{sr}^{-1}\right.$ or $\left.\mathrm{LR}>50 \mathrm{sr}\right)$.

\subsection{Sun photometer}

The Cimel ${ }^{\circledR}$ sun photometer is part of the Aerosol Robotic Network (AERONET; http://aeronet.gsfc.nasa.gov/cgi-bin/ type_piece_of_map_opera_v2_new; Holben et al., 1998). It performs measurements of solar light extinction at eight wavelengths in the solar spectrum between 340 and $1020 \mathrm{~nm}$ to retrieve the AOT at seven wavelengths. The instrument field of view is about $1^{\circ}$, and the channel bandwidths are less than $20 \mathrm{~nm}$. The instrument was calibrated prior to and after the campaign by the observation service Photométrie pour le Traitement Opérationnel de Normalisation Satellitaire (PHOTONS; http://loaphotons.univ-lille1. $\mathrm{fr} /$ ), the French component of AERONET. We have used Level-2 quality-assured data. The AOT is retrieved with a maximal absolute uncertainty of 0.02 , independent of the aerosol load. The aerosol optical thickness at the lidar wavelength of $355 \mathrm{~nm}\left(\mathrm{AOT}_{355}\right)$ has been assessed using the Ångström exponent (Ångström, 1964) and the sunphotometer AOT at 380 and $440 \mathrm{~nm}$. Sun-photometer AOT values at 500 and $675 \mathrm{~nm}$ are also used in this work for a better comparison to satellite products described below. Additionally, these measurements were checked against and completed by a SOLAR Light ${ }^{\circledR}$ Microtops II manual sun photometer, calibrated by PHOTONS shortly before the campaign (AERONET instrument no. 695). The AOT accuracy is similar to that of the automated Cimel sun photometer. Nevertheless, manual solar targeting induces an additional bias, which leads to an absolute uncertainty of the order of 0.04 as 


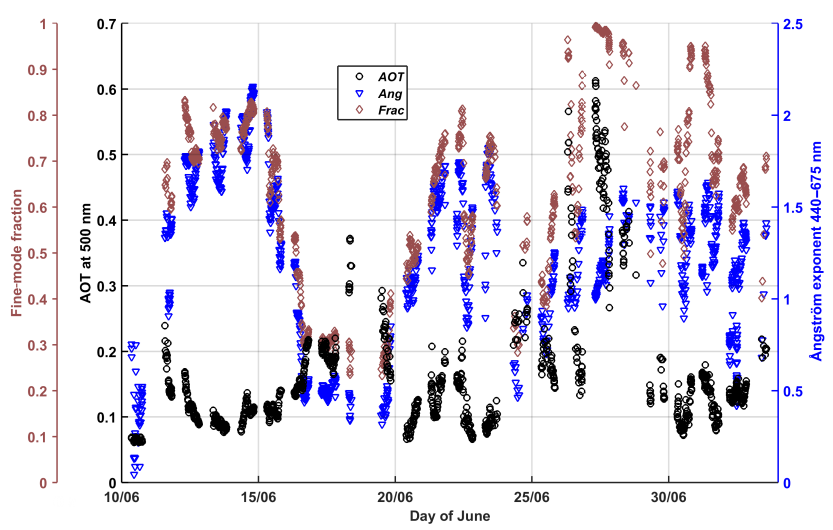

Figure 3. Temporal evolution between 10 June and 3 July 2013, local time, of the aerosol optical thickness at $500 \mathrm{~nm}$ (AOT), the Ångström exponent between 440 and $675 \mathrm{~nm}$ (Ang) and the finemode fraction (Frac) as derived from the sun-photometer measurements at Cap d'en Font. The AERONET products are completed by the Microtops II manual sun-photometer measurements on 10 June.

compared to simultaneous measurements by an automated sun photometer.

\section{Temporal continuity of the aerosol optical properties}

\subsection{Vertically integrated aerosol optical properties derived from the sun photometer}

Both times series of AOT at $500 \mathrm{~nm}\left(\mathrm{AOT}_{500}\right)$ and Ångström exponent between 440 and $675 \mathrm{~nm}$, as directly measured by the sun photometer, are plotted in Fig. 3.

AOT and Ångström exponent both exhibit a strong variability due to the succession of aerosol events of different types, as revealed by the large range of variation of the Angström exponent between $\sim 0.4$ and 2.15. The finemode fraction of AOT also reported in the figure clearly covaries with the Ångström exponent. The coarse-mode contribution is dominant from 16 to 20 June (coarse-mode fraction of AOT between 50 and $80 \%$ ) and also important on 24-25 June (35-70\%). The AOT appears to be higher with values larger than 0.2 during such periods. The AOT, which is below 0.38 (on 18 June) during the first 2 weeks of campaign, significantly increases on 26-28 June, showing several maxima (up to more than 0.6 on 27 June). Variations with particularly large amplitudes appear on the 26 and 27 June. Usually such peaks are due to northern African dust aerosol transport over the western Mediterranean basin (e.g. Moulin et al., 1998; Hamonou et al., 1999). In our case, the Ångström exponent ranging between 1 and 1.6 appears too high to support the hypothesis of a dominant presence of dust particles. Values of the Ångström exponent over 1.5 are typical of pollution-like or biomass burning aerosols (Chazette et al., 2005b), and an average value of 1.80 has been observed for non-dust conditions over the Mediterranean by Paronis (a)
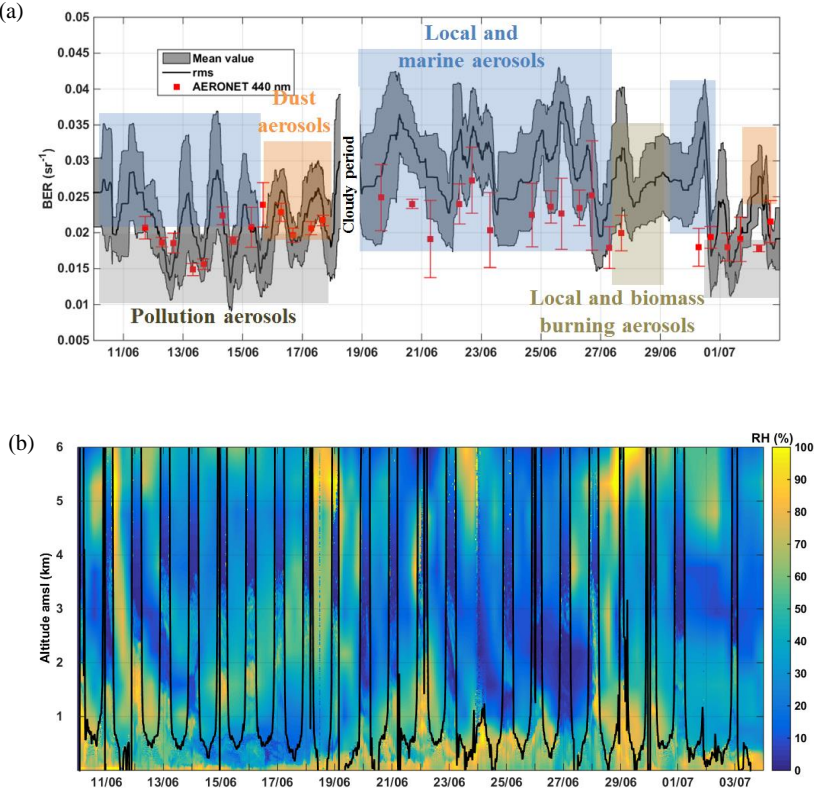

Figure 4. Temporal evolution of (a) the backscatter-to-extinction ratio (BER) and (b) the relative humidity (RH) between 10 and 29 June 2013. In (a) the root mean square error (RMSE) is given by the grey area. The main aerosol categories have been identified in the figure as pollution, dust, local, marine and biomass burning aerosols using BER and PDR values (see text). The sun-photometerderived BER is superimposed in red with its standard deviation (variability over half a day). In (b) the RH is calculated from lidar measurements using the thermodynamic temperature given by ECMWF analyses. During daytime the RH in the free troposphere is that of ECMWF; the boundary between the two RH determinations is highlighted by the continuous black line.

et al. (1998). Computations by Hamonou et al. (1999) suggest that a dust contribution to this AOT cannot be excluded but should be under a 0.45 fraction for the observed range of Ångström exponent. The lowest AOT values observed on 10 June together with a low range of Ångström exponent (0.01-0.21) are typical of a clear marine atmosphere with an aerosol population dominated by sea-salt particles. We note that the uncertainty on the Ångström exponent grows as the AOT decreases. For AOT $<0.15$, the meaning of the Ångström exponent is subject to caution.

\subsection{Aerosol optical properties derived from the ground-based lidar WALI}

The temporal evolutions of the BER derived from both the lidar measurements and the sun photometer are compared in Fig. 4. The sun-photometer-derived column-integrated BER of the aerosols can be computed at $440 \mathrm{~nm}$ from the single scattering albedo and the backscatter phase function derived from the operational algorithm of AERONET (Dubovik and King, 2000). The root mean square error (RMSE in grey area) on the lidar-derived BER, determined as the variabil- 
ity over $20 \mathrm{~min}$, is close to $0.004 \mathrm{sr}^{-1}$ on average, which is comparable with the one retrieved by Chazette et al. (2012b) with a similar lidar system set-up in Minorca in the 2012 autumn season. We note a good coherence with the BER at $440 \mathrm{~nm}$ derived by the AERONET sun photometer. Yet, the sun-photometer-derived BER seems to be underestimated by $\sim 0.004-0.01 \mathrm{sr}^{-1}$ comparatively with the lidar between 19 and 26 June; the larger variability bars at this period are due to a lighter aerosol load (see Fig. 3), which may explain part of this discrepancy. The higher values of BER seen by the lidar would also be consistent with the hygroscopic properties of aerosols within the PBL where the relative humidity significantly increases (Fig. 4b) to reach more than $90 \%$. Indeed, BER may increase with the growth of aerosols. Moreover, the surface wind speed rose on 26 June, with gusts reaching $12 \mathrm{~m} \mathrm{~s}^{-1}$, which may feed the atmosphere with marine aerosols (Blanchard et al., 1984).

For the sake of checking the consistency between the inversion procedures used during nighttime and daytime, the histograms of the equivalent BER are compared in Fig. 5 for daytime, nighttime and the whole day. These histograms account for all lidar data inverted in cloud-free conditions. The values greater than $0.045 \mathrm{sr}^{-1}$ are not significant and may represent situations where the inversion process does not converge. Hence, $\sim 10 \%$ of lidar profiles have not been considered in the synthesis. The nighttime BER distribution, with a BER value of $0.024 \pm 0.008 \mathrm{sr}^{-1}$, is only slightly smaller than the daytime distribution $\left(0.026 \pm 0.007 \mathrm{sr}^{-1}\right)$. Hence, the BER values are deemed consistent between daytime and nighttime, and the synthesis on the entire experiment period shows an average of $0.024 \pm 0.008 \mathrm{sr}^{-1}$ (LR $41.7 \pm 14 \mathrm{sr})$.

The temporal evolutions of the vertical profile of aerosol extinction coefficient and PDR are shown in Fig. 6. PDR is an effective parameter to separate the contribution of the more spherical particles from the ones due to dust-like aerosols (e.g. Chazette et al., 2012b). Between 16 and 19 June the PDR value is between 10 and $27 \%$, which is representative of non-spherical dust-like aerosols (Müller et al., 2007; Tesche et al., 2011) as identified in Fig. 4a for BER between $\sim 0.021$ and $0.028 \mathrm{sr}^{-1}$. Except between 26 and 28 June, the aerosol content is dominated by spherical particles. Between 26 and 28 June a depolarizing layer is observed between $\sim 5$ and $7 \mathrm{~km}$ a.m.s.l. The PDR ranges between 8 and $14 \%$ suggesting that dust aerosols were mixed with other aerosol sources or were processed during their transport to Minorca. We will further discuss this case in Sect. 4. When considering the temporal evolution of AOT also given in Fig. 6a, we note that lidar- and sun-photometer-derived AOTs significantly differ on several occasions, especially in the cloudy periods $(11,20,24,25$ and 27 June). This is due to residual cloud layers in the lidar profiles, which are not seen on the line of sight of the sun photometer, with a positive bias explained by the higher BER of these thin layers. In addition, from 26 to 28 June, the presence of high-altitude aerosol layers also (a)

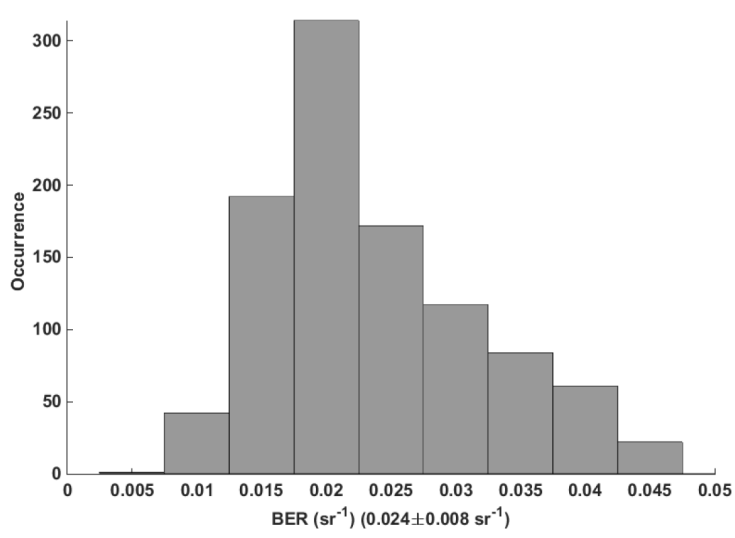

(b)

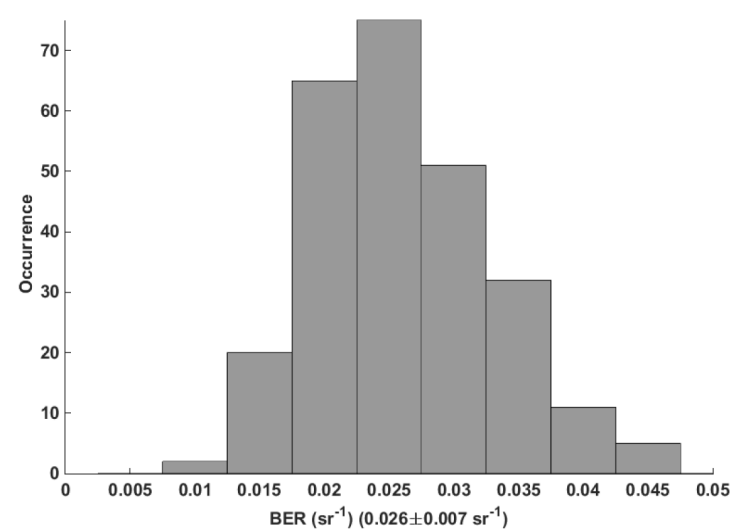

(c)

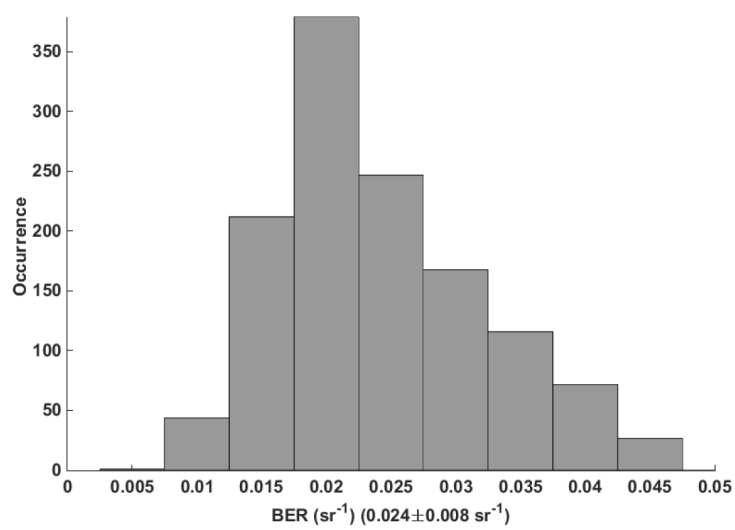

Figure 5. Backscatter-to-extinction ratio (BER) retrieved from (a) the synergy of the WALI lidar and the sun photometer during daytime, (b) the coupling between the elastic and $\mathrm{N}_{2}$-Raman channels during nighttime, and (c) the synthesis of daytime and nighttime results. 
(a)

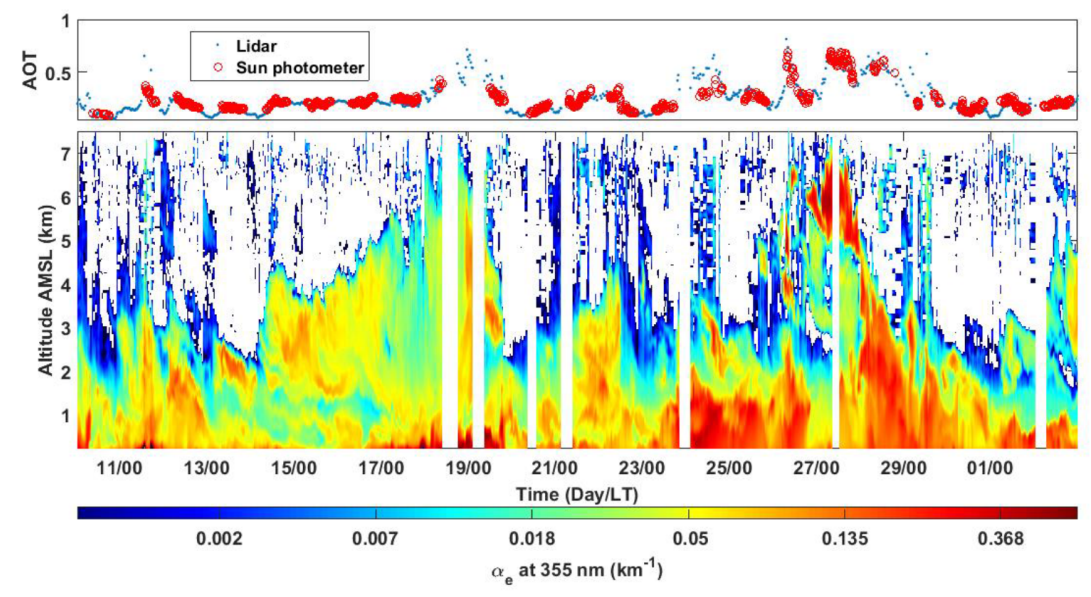

(b)

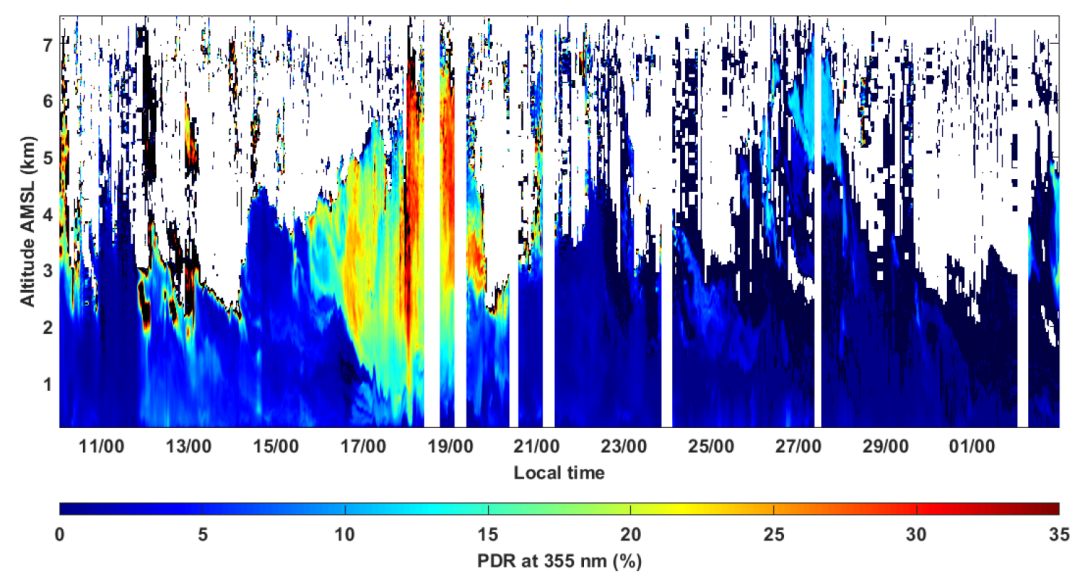

Figure 6. (a) The temporal evolution of the vertical profile of the aerosol extinction coefficient at $355 \mathrm{~nm}\left(\alpha_{\mathrm{e}}\right)$. The top panel shows AOT at $355 \mathrm{~nm}$ derived from the sun photometer (red circles) and lidar measurements (blue points). (b) The temporal evolution of the particulate depolarization ratio vertical profile at $355 \mathrm{~nm}$ (PDR). Time white stripes correspond to periods filtered out by visual examination of the lidar signal to identify the occurrence of clouds.

probably causes a strong heterogeneity of the aerosol BER in the tropospheric column (see Fig. 2b), which may explain part of the previous discrepancies because the aerosol types may be very different against the altitude. This shows the limited relevance of the notion of column-equivalent BER in heterogeneous cases.

\subsection{Evidence of contributions by aerosol type as discriminated by lidar}

The temporal evolution of the observed aerosol species can be derived from the analysis of the equivalent BER and PDR. Indeed, these two parameters, only calculated from the lidar profiles, are sufficiently discriminating to identify the main aerosol types in most cases (Burton et al., 2012). Three aerosol types are considered: (i) dust-like aerosols with values of BER and PDR centred on $0.022 \mathrm{sr}^{-1}$ and $20 \%$, respectively, (ii) pollution aerosols with BER and PDR centred on $0.015 \mathrm{sr}^{-1}$ and $2 \%$, respectively, and (iii) marine aerosols with mean values of BER and PDR centred on $0.04 \mathrm{sr}^{-1}$ and $0 \%$, respectively. For each aerosol type, literature sometimes reports a large range of values, as shown in Tables 1 and 3 of Dieudonné et al. (2015) for dust and pollution aerosols, respectively. These authors report at the same wavelength BER from 0.013 to $0.026 \mathrm{sr}^{-1}$ and PDR from 13 to $25 \%$ for pure dust or dusty mix (0.011-0.017 sr ${ }^{-1}$ and $3-5 \%$, respectively, for pollution) aerosols. This range of values includes the lidar observations performed by Groß et al. (2011) in Cabo Verde (off western Africa) with BER $=0.017-0.020 \mathrm{sr}^{-1}$ and PDR $=24-27 \%$. The same authors report BER from 0.042 to $0.053 \mathrm{sr}^{-1}$ and PDR from 1 to $2 \%$ for marine aerosols. Figure 7 gives the temporal evolution of the aerosol type after defining a specific colour map as a function of BER and PDR. The lidar profiles were here averaged during $1 \mathrm{~h}$ with a vertical resolution of $\sim 30 \mathrm{~m}$. The aerosol backscatter coefficient $(\mathrm{ABC})$ is coded by colour density: the more saturated, the larger the $\mathrm{ABC}$ (white corresponds to $\mathrm{ABC}=0$ ). A specific colour scale is affected to the couple of variables BER 


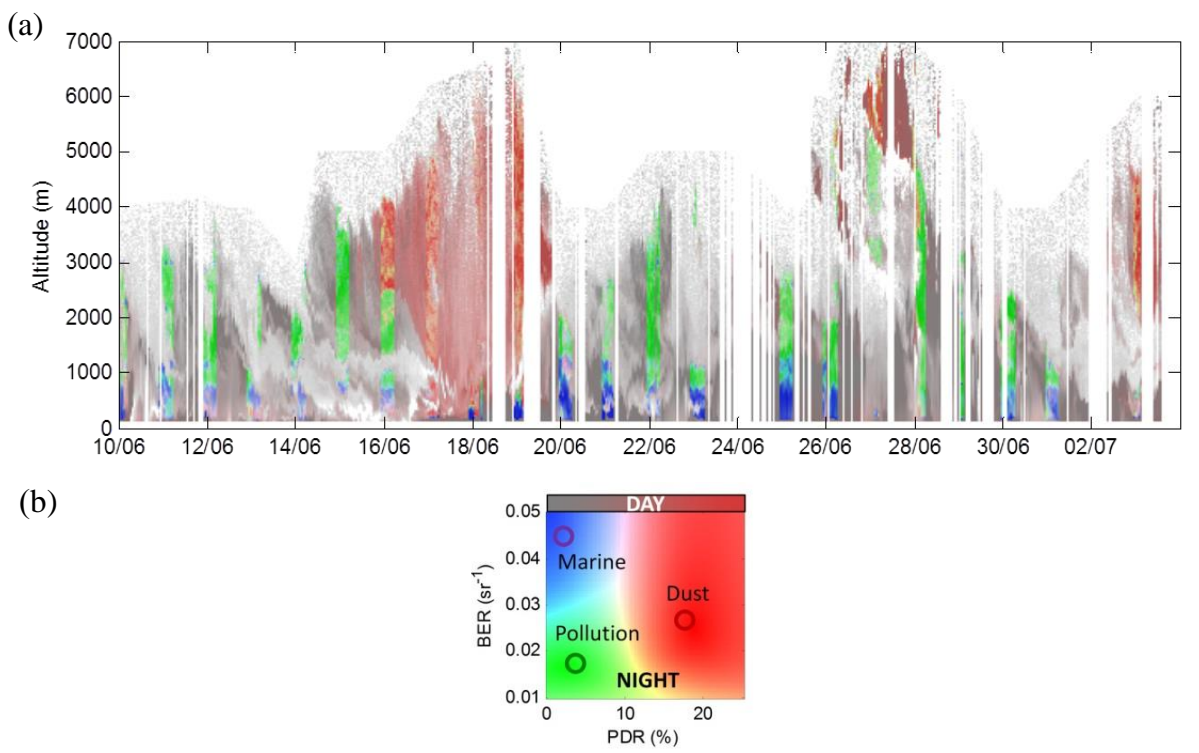

Figure 7. (a) Results of aerosol speciation as given by lidar-derived extinction, PDR and BER, with backscatter coefficient coded as saturation (no saturation, white $=0$, full saturation $=510^{-6} \mathrm{~m}^{-1} \mathrm{sr}^{-1}$ ); (b) key for the colours of the above. Nighttime: dust-, pollution- and marinelike aerosols coded as red, green and blue respectively. Daytime: PDR coded as the saturation of red (top of the colour key). Intermediate colours and grey thus designate undetermined layers where aerosol mixing may occur.

and PDR during nighttime. As the inversion using the $\mathrm{N}_{2}-$ Raman channel is not possible when the sun is up, the colour map has been only associated with the PDR during daytime.

Such a graphic representation allows the refinement of the identification of the aerosol types that are presented in Fig. 4a. The higher BERs retrieved in Fig. 4a between 19 and 26 June are due to a larger contribution of reflective aerosols in the lower layers, likely sea salt particles, which may also be very hydrophilic. Pollution aerosols are present all along the measurement period except during the dust event between 16 and 19 June. It is more difficult to attribute the layer above $5 \mathrm{~km}$ a.m.s.l. during the night of 26-27 June to a single aerosol source because depolarization is observed simultaneously with low BER. This layer arrives above a layer of biomass burning or polluted aerosols which spread between $\sim 3$ and $5 \mathrm{~km}$ a.m.s.l. A succession of pollution plumes originated from different locations along the Spanish coast contributes to the aerosol pollution load in the lower free troposphere over Minorca according to the air mass trajectories (not shown). The intermittent plumes, lifted as the PBL develops over Spain each afternoon, explain the periodic behaviour observed in Fig. 4a for the temporal evolution of the column-equivalent BER. However for the 26-27 June period the long-range transport, revealed by the back trajectories discussed hereafter, also shows a link with the North American biomass burning aerosol sources. Note that long-range transport of biomass burning aerosols has always demonstrated to be a significant aerosol source over Europe (e.g. Fiebig et al., 2003; Müller et al., 2005). This temporal evolution of aerosol types based on the unique analysis of the lidar data is quite consistent with the column-integrated observations of the AERONET sun photometer, as discussed in Sect. 3.1 and reported in Fig. 3.

\subsection{Regional representativeness as seen by spaceborne measurements}

The observations conducted from the Minorca station are relevant to the local atmospheric column. In the following we put them in a more regional context using the measurements performed by SEVIRI (e.g. Bennouna et al., 2009) and the spaceborne instrument Moderate Resolution Imaging Spectroradiometers (MODIS; Salmonson et al., 1989; King et al., 1992; http://modis.gsfc.nasa.gov). The MODIS data above land (few data are available above sea due to sun glitter) and the SEVIRI data above sea are combined in a single map to check the reliability in terms of continuity between sea and continent.

The spatial resolution of the MYD04_L2 product of MODIS is $10 \times 10 \mathrm{~km}^{2}$ at nadir. The predicted uncertainty on the AOT at $550 \mathrm{~nm}$ over land is $\pm 0.15 \times$ AOT \pm 0.05 . The spatial and temporal resolutions of SEVIRI measurements are $10 \times 10 \mathrm{~km}^{2}$ and $15 \mathrm{~min}$, respectively. The uncertainty on the SEVIRI-derived AOT is very dependent on the aerosol type (Bennouna et al., 2009). Compared to AERONET products from coastal stations, Thieuleux et al. (2005) do not highlight any significant bias on the AOT at $550 \mathrm{~nm}$ derived from SEVIRI for values between $\sim 0.07$ and 1 . Their comparison based on observations in 2003 indicates that the SEVIRI AOT product is of somewhat lower quality at the sunphotometer sites directly affected by a desert dust plume 
(a)

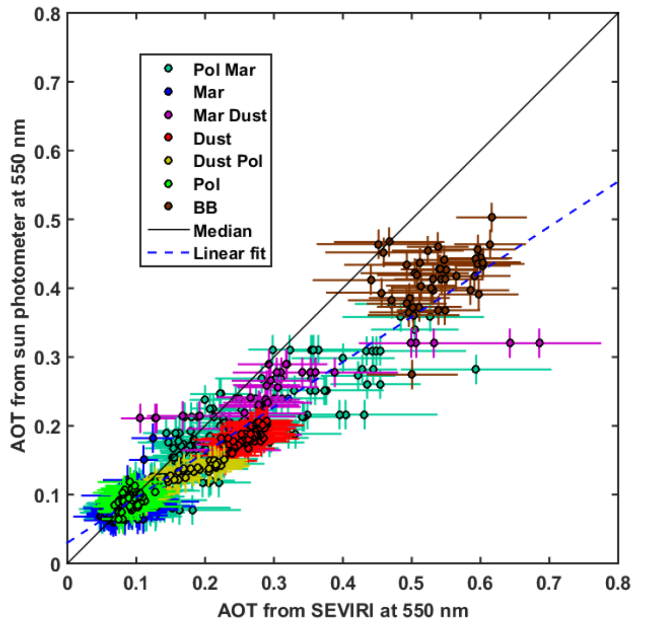

(b)

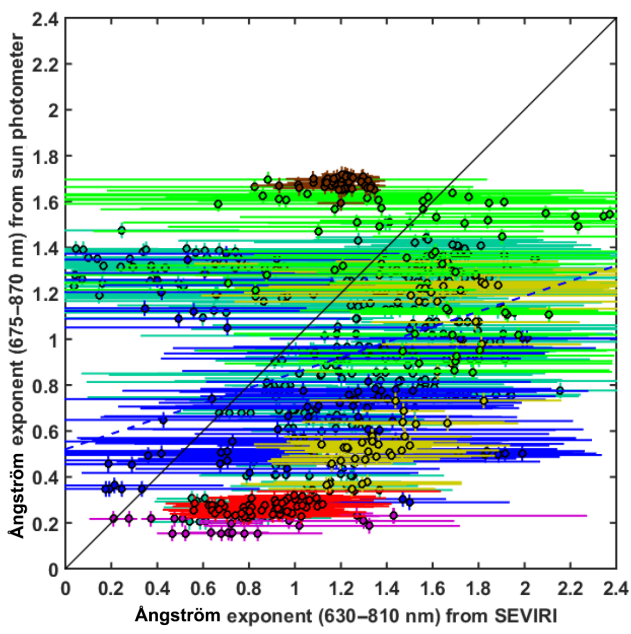

Figure 8. (a) Scatter plots between SEVIRI and the ground-based sun photometer of Minorca for the aerosol optical thickness AOT at $550 \mathrm{~nm}$. The dotted line corresponds to the best fit against both retrievals. (b) The Ångström exponent for similar spectral ranges. A total of 846 coincident data pairs between 10 and 30 June are available for comparison. To the four aerosol types identified in Fig. 7, three mixed types are added which are all distinguished by their colour: pollution (Pol), dust (Dust), marine (Mar) and biomass burning (BB), mixing of pollution and marine (Pol Mar), marine and dust (Mar Dust), dust and pollution (Dust Pol). The black solid curve represents the identity line.

from northern Africa. This is attributed to the fact that the aerosol models used to compute the look-up table do not include a specific desert dust model. Bréon et al. (2011) report a bias of 0.07 from their more exhaustive evaluation with AERONET sun photometers over the period from June 2005 to December 2010. From a similar linear fitting between MODIS and AERONET, they found a smaller bias of $\sim 0.02$ and a correlation slope close to 1 .

Figure 8 shows the inter-comparison between quarterhourly products from SEVIRI and from the coincident AERONET sun photometer of Minorca, including the AOT at $550 \mathrm{~nm}$ (Fig. 8a) and the Ångström exponent (Fig. 8b, computed between 630 and $810 \mathrm{~nm}$, and 675 and $870 \mathrm{~nm}$ for SEVIRI and the sun photometer, respectively). For the AOT, a linear least square fit highlights a significant deviation from the identity line with a factor of 0.65 . The additive bias is low, positive and close to 0.03. The mean RMSE is $\sim 0.066$. The main discrepancies are mostly observed for the highest AOTs, occurring between 17-19 and 26-28 June when marine and dust aerosol are mixed and when biomass burning aerosols arrived above the site. The latter case is likely also associated with aerosol mixing. The discrepancies can be due to the resulting difficulty of the inversion process to identify a proper aerosol model, even for dust particles which never completely prevail in terms of AOT. We note the larger dispersions for the mixing of marine particles with dust or pollution aerosols. In the following, we have corrected by $-35 \%$ the SEVIRI AOT 550 product. Whereas the sun-photometer-derived Ångström exponent seems coherent with our previous classification, our results suggest that the SEVIRI Ångström exponent product (Fig. 8b) has relatively large discrepancies at all AOTs, mostly related to aerosol type and microphysical properties. The dispersion is lower for the dust (red in the figure) and biomass burning (brown in the figure) events, but with overestimation and underestimation, respectively. Consequently, the SEVIRI-derived $\mathrm{AOT}_{550}$ product over ocean, which relies on the evaluated Ångström exponent, should be carefully checked before use. Note that these conclusions on both AOT and Ångström exponent cannot be generalized to other areas or other time periods without further investigation.

The situations with the strongest AOT contrasts above the western Mediterranean basin are shown in Fig. 9. We can note the very good continuity, after the correction of the SEVERI-derived AOT, between sea and continent (MODISderived AOT). The main aerosol events are linked with either the highest PDR observed between 16 and 19 June, or the highest-altitude transport (above $5 \mathrm{~km}$ a.m.s.l.) between 26 and 28 June. The first event is due to desert dust aerosols off the Moroccan and Algerian coasts (see also Fig. 4). The second event reveals a plume crossing the Mediterranean from north to south and will be discussed hereafter. It is associated with a decrease of the BER after 26 June as shown in Fig. 4a.

\section{Discussion}

The pollution transport events observed at Minorca in the first part of the campaign, 12-18 June (Fig. 4), are associated with the lowest values of the BER. To investigate their origins, we ran the HYbrid Single-Particle Lagrangian Integrated Trajectory (HYSPLIT) model (Draxler and Rolph, 2014) with 3-hourly archived meteorological data provided by the US National Center for Environmental Prediction (NCEP) Global Data Assimilation System (GDAS) at the horizontal resolution of $0.5^{\circ}$. Two-day back trajectories (not 
(a)

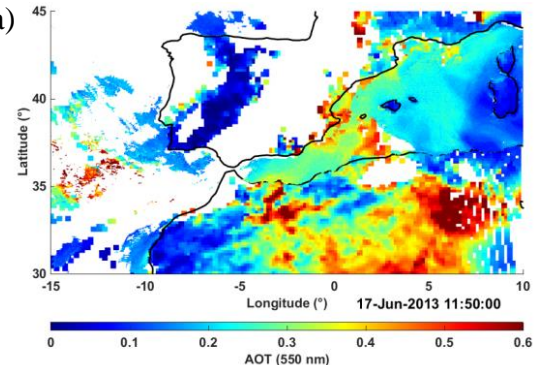

(c)

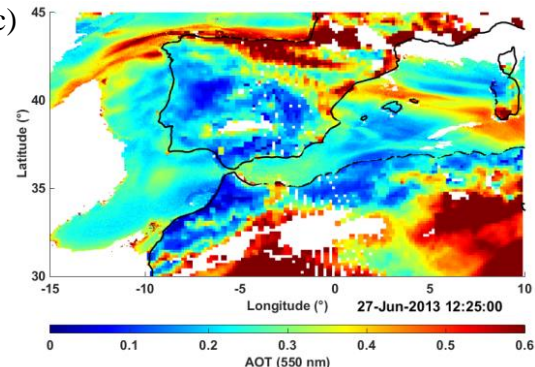

(b)

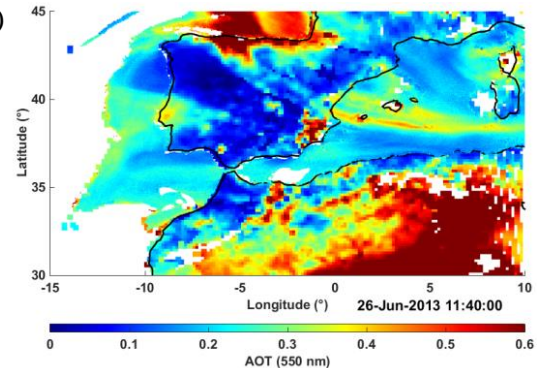

(d)

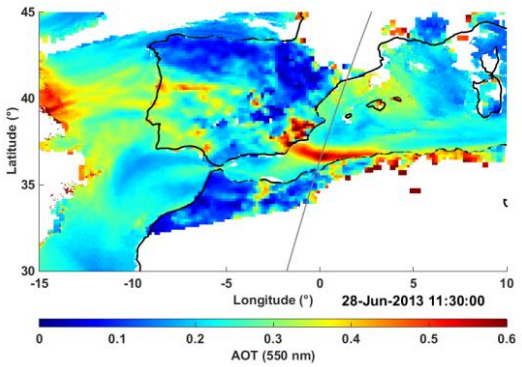

Figure 9. AOT composition between the MODIS observations over land and SEVIRI over sea. The SEVIRI AOT was corrected by a factor 0.65 as identified from comparisons with the sun photometer reported in Fig. 8: (a) 17 June, (b) 26 June, (c) 27 June and (d) 28 June. For 28 June the nighttime CALIOP ground track (at about 02:00 UTC) is marked by a continuous grey line.

shown) clearly trace those polluted air masses back to Spain. Still in the same period, we note an increase of the BER during nighttime. It may be due to a higher relative contribution of hygroscopic aerosols below $1 \mathrm{~km}$ a.m.s.l. as explained in Sect. 3. Between 18 and 26 June (Fig. 4), the BER reaches $\sim 0.04 \mathrm{sr}^{-1}(\mathrm{LR}=25 \mathrm{sr})$ as observed by Flamant et al. (2000) for marine aerosols over the open ocean. Nevertheless, we also note weak-medium surface wind speeds between 2 and $8 \mathrm{~m} \mathrm{~s}^{-1}$, which are not favourable to a strong contribution of sea salt particles in the lower troposphere.

Satellite data show the arrival of an African dust plume from the Alboran Sea over the Balearic Islands starting slowly on 15 June and leaving Minorca on 19 June. The AOT slightly increases from 16 to 18 June, when the densest part of the dust plume passes over Minorca, to reach $\mathrm{AOT}_{355}=0.25 \pm 0.05$. As highlighted by 3 -day back trajectories (not shown), the dust plume came from Morocco and Algeria, as also illustrated by the satellite image in Fig. 9a. Moreover, measurements of the Cloud-Aerosol LIdar with Orthogonal Polarization (CALIOP, PC-SCI-202.03, Vaughan et al., 2004) on 16 June highlight dust aerosols below $37.3^{\circ}$ of latitude and polluted-dust aerosols above this latitude, which confirm the classification given in Fig. 7. In the dust layer above $1 \mathrm{~km}$ a.m.s.l., the PDR is $20 \pm 5 \%$ and the mean BER (LR) is $0.024 \pm 0.002 \mathrm{sr}^{-1}(\sim 41.7 \pm 4 \mathrm{sr})$. Note that, as shown Fig. 2a and previously discussed, the BER significantly evolves within the low and medium troposphere from $0.04 \mathrm{sr}^{-1}(\mathrm{LR}=25 \mathrm{sr})$ in the MBL to $\sim 0.020$ $0.025 \mathrm{sr}^{-1}(\mathrm{LR} \sim 50-40 \mathrm{sr})$ in the dust layer situated above $\sim 2 \mathrm{~km}$ a.m.s.1. An intermediate peak is observed in the BER profile between 1 and $2 \mathrm{~km}$ a.m.s.l. associated with smaller values of the aerosol extinction coefficient (Fig. 6). This intermediate layer is associated with $\mathrm{PDR}<2 \%$ and may be mainly affected by both marine and pollution aerosols.

The high-altitude aerosol event observed between 4 and $7 \mathrm{~km}$ a.m.s.l. above the western Mediterranean basin from 26 to 28 June is not usual in its nature since it results from a very turbid plume $\left(\mathrm{AOT}_{550}>0.6\right)$ arriving from the NE Atlantic as visible on the Bay of Biscay on 26 June in Fig. 10. Formenti et al. (2002) have already documented with airborne measurements such an event of 10-day aged haze layers from Canadian fires over the eastern Mediterranean in August 1998. Seven-day back trajectories have been computed with the HYSPLIT model (Fig. 10). The back trajectories are superimposed on a MODIS AOT image combining data from 24 June 2013. Dense aerosol plumes appear all along a transport pathway over the North Atlantic, with a dark red colour associated with AOT $_{550}$ values larger than 1. Note that the AOT even reaches 5 for many pixels, maybe because cloud contribution is also included as can be seen in the true colour image available on https://earthdata.nasa.gov/ labs/worldview/. As shown in Fig. 10, the biomass burning plume observed at $6 \mathrm{~km}$ over Minorca on 27 June crossed the Atlantic Ocean at altitudes between 4 and $8 \mathrm{~km}$ a.m.s.l. The plume is associated with forest fires occurring in Canada and Colorado.

The possible source regions are discussed in detail in the companion paper of Ancellet et al. (2016). It includes contributions from two different plumes: biomass burning aerosol from North America and dust transported westward over the Atlantic by the trade winds. Trajectories from the other plume detected close to $4 \mathrm{~km}$ a.m.s.l. over Minorca by the li- 

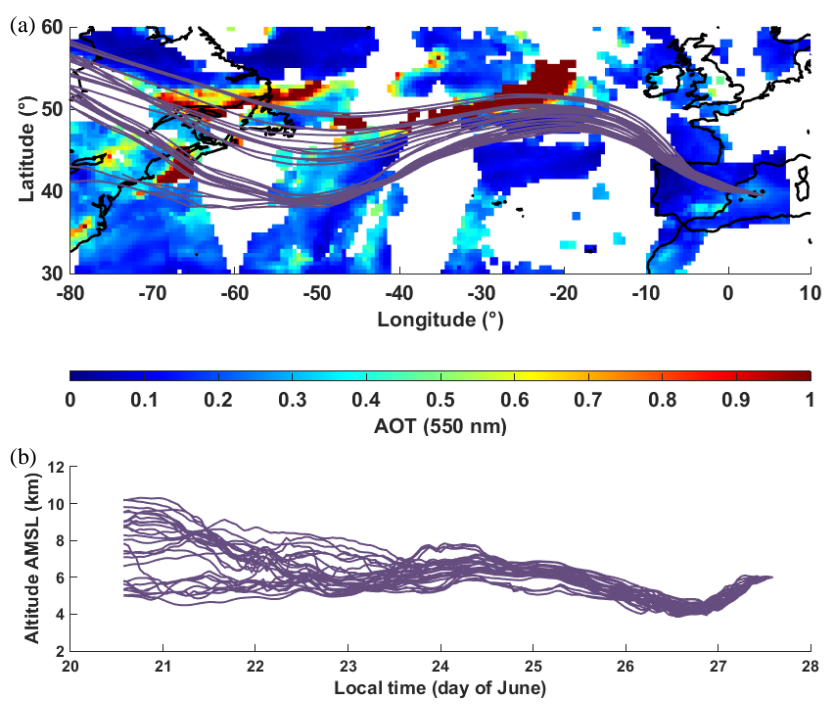

Figure 10. 27 back trajectories from Minorca $\left(39^{\circ} 51^{\prime} 44^{\prime \prime} \mathrm{N}\right.$, $\left.4^{\circ} 15^{\prime} 30^{\prime \prime} \mathrm{E}\right)$. The back trajectories have been computed using the ensemble mode of the HYSPLIT model (courtesy of NOAA Air Resources Laboratory; http://www.arl.noaa.gov). The end location of the air mass trajectories is at $6 \mathrm{~km}$ a.m.s.l. in the plume detected by the WALI lidar on 27 June 2013 over Minorca (see Fig. 6a). The top panel presents the location of each back trajectory superimposed over the MODIS-derived AOT at $550 \mathrm{~nm}$ of 24 June 2013, for several orbits. The bottom panel shows the altitude of the back trajectories against time.

dar on 28 June (Fig. 6) also come from North America with little contribution from the Atlantic Saharan dust. The North American aerosol event of 26-27 June is characterized by $\mathrm{AOT}_{355}=0.18 \pm 0.16$ above Minorca. It represents $\sim 50 \%$ of the total mean columnar AOT $\left(\mathrm{AOT}_{355}=0.41 \pm 0.12\right)$ encountered during this day. It is associated with a moister air mass, with a WVMR close to $1-2 \mathrm{~g} \mathrm{~kg}^{-1}$, comparatively to the clean free mid-troposphere $\left(0.5 \mathrm{~g} \mathrm{~kg}^{-1}\right)$, as derived from the $\mathrm{H}_{2} \mathrm{O}-\mathrm{Raman}$ lidar channel. The uplifting of air masses from the lower troposphere occurs either above North America or above the Atlantic Ocean as discussed in Ancellet et al. (2016). The equivalent BER has been assessed to be $0.023 \pm 0.002 \mathrm{sr}^{-1}$ (LR $\sim 43.5 \pm 4 \mathrm{sr}$ ) and corresponds to about the mean value of the vertical profile of BER given in Fig. 2b. As previously, the values retrieved in the MBL correspond to marine aerosols. The BER in the mixture of biomass burning aerosol and dust is determined as $0.025 \pm 0.002 \mathrm{sr}^{-1}$ (LR $\sim 40 \pm 3$ sr) with a PDR between 8 and $14 \%$. PDR values between 8 and $18 \%$ were measured over Cyprus by the lidar of Limassol (Nisantzi et al., 2014) for almost fresh biomass burning aerosols mixed with dust-like particles uplifted by thermal convection and transported above the lidar site. However, the dust observed over Cyprus presents a larger BER than the one generally derived over the Sahara. Groß et al. (2011) also report larger values of PDR (18-22\%) for a mixture of biomass burning and Saharan dust aerosol over Cabo Verde with BER between 0.014 and $0.016 \mathrm{sr}^{-1}$ (LR between 60 and $70 \mathrm{sr}$ ). In our case, the aerosols are more aged (at least 7 days) and may be more spherical due to water vapour condensation during transport over the Atlantic Ocean. We note cloud formation along some filaments created from the initial plume (not shown). Such a phenomenon decreases the PDR. Nevertheless, the value of PDR is higher and may indicate the presence of dust-like particles within the biomass burning plume. The high vertical resolution of the CALIOP lidar $(30-60 \mathrm{~m})$ can be processed to derive aerosol type and optical properties of the aerosol layers (e.g. Vaughan et al., 2004; Thomason et al., 2007; Kim et al., 2008; Berthier et al., 2006) as the PDR. The 8-14\% PDR measured at $355 \mathrm{~nm}$ by the WALI lidar appears comparable to the $10 \%$ PDR at $532 \mathrm{~nm}$ observed by CALIOP (the ground track is given in Fig. 9d) off the Mediterranean Spanish coast at $1^{\circ} \mathrm{E}$ in a layer between 38 and $39^{\circ} \mathrm{N}$ on 28 June, 02:00 UTC (see Ancellet et al., 2016). Over the Atlantic Ocean (24 June), the aerosol plume is identified by CALIOP measurements either of smoke type or of polluted dust type.

\section{Conclusions}

Aerosol optical properties in the tropospheric column were derived from the measurements performed continuously, during 3 weeks in June and early July 2013, at Minorca during the Chemistry-Aerosol Mediterranean Experiment/Aerosol Direct Radiative Effect in the Mediterranean (ChArMEx/ADRIMED) special observation period (SOP1a). The measurements sampled air masses with very different aerosol content and a large range of optical thicknesses $\left(\mathrm{AOT}_{355}=0.29 \pm 0.17\right)$, which is representative of the years 2011-2013 $\left(\mathrm{AOT}_{355}=0.24 \pm 0.15\right)$. There are only a few cases where the aerosol layers are not composed of a mixture of different aerosol types. They originate from the surrounding sea, the Spanish coastal cities, the northern Africa deserts and even distant forest fires in North America. We have noted that the complex mixing of aerosols likely impacts the retrieval of the AOT from SEVIRI leading to a relative bias close to $35 \%$.

The instrumental synergy, coupling either the sun photometer or the $\mathrm{N}_{2}$-Raman channel with the elastic channel, allows a well-constrained processing of the lidar measurements, from which we were able to follow the evolution of the aerosol optical properties between night and day. In particular, the continuity of column-equivalent BER measurements is ensured. Lidar observations allowed locating scattering layers in the troposphere and, in particular, identifying a complex aerosol transport from North America in the middle troposphere (between 2 and $7 \mathrm{~km}$ a.m.s.l.). Air masses took between 5 and 7 days to arrive over the Mediterranean Sea. There has been a great variability in the nature of aerosols in the troposphere from 26 to 28 June 2013. This 
variability is evidenced by the BER profile estimated from the Raman lidar WALI, with a strong variance $(B E R(L R)=$ $0.024 \pm 0.008 \mathrm{sr}^{-1}(\sim 41.7 \pm 14 \mathrm{sr})$, above $4 \mathrm{~km}$ a.m.s.l. and $<0.02 \mathrm{sr}^{-1}$ (> $50 \mathrm{sr}$ ) between 2 and $4 \mathrm{~km}$ a.m.s.l.). However, such variability has a weak impact on the AOT measurements, be it during nighttime or daytime. We have also observed the presence of depolarizing particles (PDR 8$14 \%$, at $355 \mathrm{~nm}$ ) in a biomass burning plume originating from North America corresponding to Saharan dust recirculated over the Atlantic Ocean, as discussed in the companion paper by Ancellet et al. (2016).

These results show that an assessment of the radiative budget of aerosols over the western Mediterranean basin can be easily performed by considering the average optical properties of the particles. Nevertheless, for the evaluation of atmospheric heating rates and possible associated effects on cloud formation, single scattering albedo must be taken into account, which is linked to the vertical evolution of the aerosol types given by our classification. Moreover, the single scattering albedo may be constrained by the lidar-derived BER as in Randriamiarisoa et al. (2004) or Raut and Chazette (2008). The latter has indeed been shown in this campaign to be very variable, both in time and altitude, due to the mixing of very different aerosol contributions over the Mediterranean Sea.

Acknowledgements. This work was supported by the French space agency (CNES) and the Commissariat à l'Energie Atomique (CEA). The campaign at Minorca was also supported by CNRS/INSU and Météo-France through the MISTRALS/ChArMEx programme, and by the Spanish Ministry of Science and Innovation and FEDER funds under the projects TEC2012-34575, UNPC10-4E-442 and CGL2011-13580-E/CLI. Matthieu Jeannot from LPC2E, and François Dulac and Sahar Hassanzadeh from LSCE are acknowledged for their technical help during the campaign. Juan Ramon Moreta Gonzalez and Miguel Angel Heredia Jodar from AEMET are acknowledged for AERONET data from Palma.

Edited by: O. Dubovik

\section{References}

Ancellet, G., Pelon, J., Totems, J., Chazette, P., Bazureau, A., Sicard, M., Di Iorio, T., Dulac, F., and Mallet, M.: Long range transport and mixing of aerosol sources during the 2013 North American biomass burning episode: analysis of multiple lidar observations in the Western Mediterranean basin, Atmos. Chem. Phys., accepted, 2016.

Ångström, A.: The parameters of atmospheric turbidity, Tellus, 16, 64-75, 1964.

Bennouna, Y. S., de Leeuw, G., Piazzola, J., and KurmierczykMichulec, J.: Aerosol remote sensing over the ocean using MSG-SEVIRI visible images, J. Geophys. Res., 114, D23203, doi:10.1029/2008JD011615, 2009.

Berthier, S., Chazette, P., Couvert, P., Pelon, J., Dulac, F., Thieuleux, F., Moulin, C., and Pain, T.: Desert dust aerosol columnar properties over ocean and continental Africa from Lidar in-Space Technology Experiment (LITE) and Meteosat synergy, J. Geophys. Res., 111, D21202, doi:10.1029/2005JD006999, 2006.

Blanchard, C. D., Woodcock, A. H., and Cipriano, R. J.: The vertical distribution of concentration of sea sealt in the marine atmosphere near Hawaii, Tellus B, 36, 118-125, 1984.

Bréon, F.-M. M., Vermeulen, A., and Descloitres, J.: An evaluation of satellite aerosol products against sunphotometer measurements, Remote Sens. Environ., 115, 3102-3111, doi:10.1016/j.rse.2011.06.017, 2011.

Burton, S. P., Ferrare, R. A., Hostetler, C. A., Hair, J. W., Rogers, R. R., Obland, M. D., Butler, C. F., Cook, A. L., Harper, D. B., and Froyd, K. D.: Aerosol classification using airborne High Spectral Resolution Lidar measurements methodology and examples, Atmos. Meas. Tech., 5, 73-98, doi:10.5194/amt-5-73-2012, 2012.

Cachier, H., Aulagnier, F., Sarda, R., Gautier, F., Masclet, P., Besombes, J.-L., Marchand, N., Despiau, S., Croci, D., Mallet, M., Laj, P., Marinoni, A., Deveau, P.-A., Roger, J.-C., Putaud, J.-P., Van Dingenen, R., Dell'Acqua, A., Viidanoja, J., Martins-Dos Santos, S., Liousse, C., Cousin, F., Rosset, R., Gardrat, E., and Galy-Lacaux, C.: Aerosol studies during the ESCOMPTE experiment: an overview, Atmos. Res., 74, 547-563, 2005.

Chazette, P.: The monsoon aerosol extinction properties at Goa during INDOEX as measured with lidar, J. Geophys. Res., 108, 4187, doi:10.1029/2002JD002074, 2003.

Chazette, P., Couvert, P., Randriamiarisoa, H., Sanak, J., Bonsang, B., Moral, P., Berthier, S., Salanave, S., and Toussaint, F.: Three-dimensional surveyof pollution during winter in French Alps valleys, Atmos. Environ., 39, 1035-1047, 2005a.

Chazette, P., Randriamiarisoa, H., Sanak, J., Couvert, P., and Flamant, C.: Optical properties of urban aerosol from airborne and ground-based in situ measurements performed during the Etude et Simulation de la Qualité de l'air en Ile de France (ESQUIF) program, J. Geophys. Res., 110, D02206, doi:10.1029/2004JD004810, 2005b.

Chazette, P., Bocquet, M., Royer, P., Winiarek, V., Raut, J. C., Labazuy, P., Gouhier, M., Lardier, M., and Cariou, J. P.: Eyjafjallajökull ash concentrations derived from both lidar and modeling, J. Geophys. Res.-Atmos., 117, D00U14, doi:10.1029/2011JD015755, 2012a.

Chazette, P., Dabas, A., Sanak, J., Lardier, M., and Royer, P.: French airborne lidar measurements for Eyjafjallajökull ash plume survey, Atmos. Chem. Phys., 12, 7059-7072, doi:10.5194/acp-127059-2012, 2012b.

Chazette, P., Marnas, F., and Totems, J.: The mobile Water vapor Aerosol Raman LIdar and its implication in the framework of the HyMeX and ChArMEx programs: application to a dust transport process, Atmos. Meas. Tech., 7, 1629-1647, doi:10.5194/amt-71629-2014, 2014.

Cros, B., Durand, P., Cachier, H., Drobinski, P., Fréjafon, E., Kottmeier, C., Perros, P., Peuch, V., Ponche, J.-L., Robin, D., Said, F., Toupance, G., and Wotham, H.: The ESCOMPTE Program: an overview, Atmos. Res., 69, 241-279, 2004.

Dieudonné, E., Chazette, P., Marnas, F., Totems, J., and Shang, X.: Lidar profiling of aerosol optical properties from Paris to Lake Baikal (Siberia), Atmos. Chem. Phys., 15, 5007-5026, doi:10.5194/acp-15-5007-2015, 2015. 
Di Iorio, T., di Sarra, A., Junkermann, W., Cacciani, M., Fiocco, G., and Fuà, D.: Tropospheric aerosols in the Mediterranean: 1. Microphysical and optical properties, J. Geophys. Res., 108, D02201, doi:10.1029/2002JD002815, 2003.

Draxler, R. R. R. and Rolph, G. D. D.: HYSPLIT (HYbrid SingleParticle Lagrangian Integrated Trajectory) Model access via NOAA ARL READY Website, available at: http://www.arl.noaa. gov/HYSPLIT.php (last access: November 2015), NOAA Air Resources Laboratory, College Park, MD, 2014.

Dubovik, O. and King, M. D.: A flexible inversion algorithm for retrieval of aerosol optical properties from Sun and sky radiance measurements, J. Geophys. Res.-Atmos., 105, 20673-20696, doi:10.1029/2000JD900282, 2000.

Dulac, F. and Chazette, P.: Airborne study of a multi-layer aerosol structure in the eastern Mediterranean observed with the airborne polarized lidar ALEX during a STAAARTE campaign (7 June 1997), Atmos. Chem. Phys., 3, 1817-1831, doi:10.5194/acp-31817-2003, 2003.

Fiebig, M., Stohl, A., Wendisch, M., Eckhardt, S., and Petzold, A.: Dependence of solar radiative forcing of forest fire aerosol on ageing and state of mixture, Atmos. Chem. Phys., 3, 881-891, doi:10.5194/acp-3-881-2003, 2003.

Flamant, C., Pelon, J., Chazette, P., Trouillet, V., Quinn, P. K., Frouin, R., Bruneau, D., Francois Leon, J., Bates, T. S., Johnson, J., and Livingston, J.: Airborne lidar measurements of aerosol spatial distribution and optical properties over the Atlantic Ocean during a European pollution outbreak of ACE-2, Tellus B, 52, 662-677, doi:10.1034/j.1600-0889.2000.00083.x, 2000.

Formenti, P., Boucher, O., Reiner, T., Sprung, D., Andreae, M. A., Wendisch, M., Wex, H., Kindred, D., Tzortziou, M., Vasaras, A., and Zerefos, C.: STAAARTE-MED 1998 summer airborne measurements over the Aegean Sea. 2. Aerosol scattering and absorption, and radiative calculations, J. Geophys. Res., 107, 4451, doi:10.1029/2001JD001536, 2002.

Giorgi, F. and Lionello, P.: Climate change projections for the Mediterranean region, Global Planet. Change, 63, 90-104, doi:10.1016/j.gloplacha.2007.09.005, 2008.

Gobbi, G. P., Barnaba, F., Blumthaler, M., Labow, G., and Herman, J. L.: Observed effects of particles nonsphericity on the retrieval of marine and desert dust aerosol optical depth by lidar, Atmos. Res., 61, 1-14, 2000.

Groß, S., Tesche, M., Freudenthaler, V., Toledano, C., Wiegner, M., Ansmann, A., Althausen, D., and Seefeldner, M.: Characterization of Saharan dust, marine aerosols and mixtures of biomassburning aerosols and dust by means of multi-wavelength depolarization and Raman lidar measurements during SAMUM 2, Tellus B, 63, 706-724, 2011.

Hamonou, E., Chazette, P., Balis, D., Dulac, F., Schneider, X., Galani, E., Ancellet, G., and Papayannis, A.: Characterization of the vertical structure of Saharan dust export to the Mediterranean Basin, J. Geophys. Res., 104, 22257, doi:10.1029/1999JD900257, 1999.

Holben, B. N., Eck, T. F., Slutsker, I., Tanré, D., Buis, J. P., Setzer, A., Vermote, E. F., Reagan, J. A., Kaufman, Y. J., Nakajima, T., Lavenu, F., Jankowiak, I., and Smirnov, A.: AERONET - a federated instrument network and data archive for aerosol characterization, Remote Sens. Environ., 66, 1-16, 1998.
IPCC: Climate Change 2014: Impacts, Adaptation, and Vulnerability. Part A: Global and Sectoral Aspects. Contribution of Working Group II to the Fifth Assessment Report of the Intergovernmental Panel on Climate Change, edited by: Field, C. B., Barros, V. R., Dokken, D. J., Mach, K. J., Mastrandresa, M. D., Bilir, T. E., Chatterjee, M., Ebi, K. L., Estrada, Y. O., Genova, R. C., Girma, B., Kissel, E. S., Levy, A. N., MacCracken, S., Mastrandrea, P. R., and White, L. L., Cambridge University Press, Cambridge, UK and new York, NY, USA, 1132 pp., 2014.

Kim, S.-W., Berthier, S., Raut, J.-C., Chazette, P., Dulac, F., and Yoon, S.-C.: Validation of aerosol and cloud layer structures from the space-borne lidar CALIOP using a ground-based lidar in Seoul, Korea, Atmos. Chem. Phys., 8, 3705-3720, doi:10.5194/acp-8-3705-2008, 2008.

King, M. D., Kaufman, Y. J., Menzel, P., and Tanré, D.: Remotesensing of cloud, aerosol, and water-vapor properties from the Moderate Resolution Imaging Spectroradiometer (MODIS), IEEE T. Geosci. Remote, 30, 2-27, 1992.

Klett, J. D.: Lidar inversion with variable backscatter/extinction ratios, Appl. Optics, 24, 1638, doi:10.1364/AO.24.001638, 1985.

Lelieveld, J., Berresheim, H., Borrmann, S., Crutzen, P. J., Dentener, F. J., Fischer, H., Feichter, J., Flatau, P. J., Heland, J., Holzinger, R., Korrmann, R., Lawrence, M. G., Levin, Z., Markowicz, K. M., Mihalopoulos, N., Minikin, A., Ramanathan, V., de Reus, M., Roelofs, G. J., Scheeren, H. A., Sciare, J., Schlager, H., Schultz, M., Siegmund, P., Steil, B., Stephanou, E. G., Stier, P., Traub, M.,Warneke, C., Williams, J., and Ziereis, H.: Global air pollution crossroads over the Mediterranean, Science, 298, 794-799, 2002.

Levin, Z., Teller, A., and Ganor, E.: On the interactions of mineral dust, sea-salt particles, and clouds: a measurement and modeling study from the Mediterranean Israeli Dust Experiment campaign, J. Geophys. Res., 110, D05207, doi:10.1029/2005JD005810, 2005.

Mallet, M., Dulac, F., Formenti, P., Nabat, P., Sciare, J., Roberts, G., Pelon, J., Ancellet, G., Tanré, D., Parol, F., Denjean, C., Brogniez, G., di Sarra, A., Alados-Arboledas, L., Arndt, J., Auriol, F., Blarel, L., Bourrianne, T., Chazette, P., Chevaillier, S., Claeys, M., D’Anna, B., Derimian, Y., Desboeufs, K., Di Iorio, T., Doussin, J.-F., Durand, P., Féron, A., Freney, E., Gaimoz, C., Goloub, P., Gómez-Amo, J. L., Granados-Muñoz, M. J., Grand, N., Hamonou, E., Jankowiak, I., Jeannot, M., Léon, J.-F., Maillé, M., Mailler, S., Meloni, D., Menut, L., Momboisse, G., Nicolas, J., Podvin, T., Pont, V., Rea, G., Renard, J.-B., Roblou, L., Schepanski, K., Schwarzenboeck, A., Sellegri, K., Sicard, M., Solmon, F., Somot, S., Torres, B, Totems, J., Triquet, S., Verdier, N., Verwaerde, C., Waquet, F., Wenger, J., and Zapf, P.: Overview of the Chemistry-Aerosol Mediterranean Experiment/Aerosol Direct Radiative Forcing on the Mediterranean Climate (ChArMEx/ADRIMED) summer 2013 campaign, Atmos. Chem. Phys., 16, 455-504, doi:10.5194/acp-16-455-2016, 2016.

Moulin, C., Lambert, C. E., Dayan, U., Masson, V., Ramonet, M., Bousquet, P., Legrand, M., Balkanski, Y. J., Guelle, W., Marticorena, B., Bergametti, G., and Dulac, F.: Satellite climatology of African dust transport in the Mediterranean atmosphere, J. Geophys. Res., 103, 13137-13144, 1998.

Müller, D., Mattis, I., Ansmann, A., Wandinger, U., Ritter, C., and Kaiser, D.: Raman lidar observations of aged Siberian and Cana- 
dian forest fire smoke in the free troposphere over Germany in 2003: Microphysical particle characterization, J. Geophys. Res., 110, D17201, doi:10.1029/2004JD005756, 2005.

Müller, D., Ansmann, A., Mattis, I., Tesche, M., Wandinger, U., Althausen, D., and Pisani, G.: Aerosol-type-dependent lidar ratios observed with Raman lidar, J. Geophys. Res.-Atmos., 112, D16202, doi:10.1029/2006JD008292, 2007.

Nabat, P., Somot, S., Mallet, M., Chiapello, I., Morcrette, J. J., Solmon, F., Szopa, S., Dulac, F., Collins, W., Ghan, S., Horowitz, L. W., Lamarque, J. F., Lee, Y. H., Naik, V., Nagashima, T., Shindell, D., and Skeie, R.: A 4-D climatology (1979-2009) of the monthly tropospheric aerosol optical depth distribution over the Mediterranean region from a comparative evaluation and blending of remote sensing and model products, Atmos. Meas. Tech., 6, 1287-1314, doi:10.5194/amt-6-12872013, 2013.

Nabat, P., Somot, S., Mallet, M., Michou, M., Sevault, F., Driouech, F., Meloni, D., di Sarra, A., Di Biagio, C., Formenti, P., Sicard, M., Léon, J.-F., and Bouin, M.-N.: Dust aerosol radiative effects during summer 2012 simulated with a coupled regional aerosolatmosphere-ocean model over the Mediterranean, Atmos. Chem. Phys., 15, 3303-3326, doi:10.5194/acp-15-3303-2015, 2015.

Nisantzi, A., Mamouri, R. E., Ansmann, A., and Hadjimitsis, D.: Injection of mineral dust into the free troposphere during fire events observed with polarization lidar at Limassol, Cyprus, Atmos. Chem. Phys., 14, 12155-12165, doi:10.5194/acp-1412155-2014, 2014

Papayannis, A., Amiridis, V., Mona, L., Tsaknakis, G., Balis, D., Bösenberg, J., Chaikovski, A., De Tomasi, F., Grigorov, I., Mattis, I., Mitev, V., Müller, D., Nickovic, S., Pérez, C., Pietruczuk, A., Pisani, G., Ravetta, F., Rizi, V., Sicard, M., Trickl, T., Wiegner, M., Gerding, M., Mamouri, R. E., D’Amico, G., and Pappalardo, G.: Systematic lidar observations of Saharan dust over Europe in the frame of EARLINET (2000-2002), J. Geophys. Res., 113, D10204, doi:10.1029/2007JD009028, 2008.

Paronis, D., Dulac, F., Chazette, P., Hamonou, E., and Liberti, G. L.: Aerosol optical thickness monitoring in the Mediterranean, J. Aerosol Sci., 29, S671-S672, 1998.
Randriamiarisoa, H., Chazette, P., and Megie, G.: Retrieving the aerosol single-scattering albedo from the $\mathrm{NO}_{2}$ photolysis rate coefficient, Tellus B, 56, 118-127, doi:10.3402/tellusb.v56i2.16408, 2004.

Raut, J.-C. and Chazette, P.: Radiative budget in the presence of multi-layered aerosol structures in the framework of AMMA SOP-0, Atmos. Chem. Phys., 8, 6839-6864, doi:10.5194/acp-86839-2008, 2008.

Royer, P., Chazette, P., Lardier, M., and Sauvage, L.: Aerosol content survey by mini $\mathrm{N}_{2}$-Raman lidar: application to local and long-range transport aerosols, Atmos. Environ., 45, 7487-7495, 2011.

Salmonson, V. V., Barnes, W. L., Maymon, P. W., Montgomery, H. E. and Ostrow, H.: MODIS: Advanced Facility Instrument for Studies of the Earth as a System, IEEE Trans. Geosci. Remote Sens., 27, 145-153, 1989.

Tesche, M., Gross, S., Ansmann, A., Müller, D., Althausen, D., and Freudenthaler, V., and Esselborn, M.: Profiling of Saharan dust and biomass-burning smoke with multiwavelength polarization Raman lidar at Cape Verde, Tellus B, 63, 649-676, doi:10.1111/j.1600-0889.2011.00548.x, 2011.

Thieuleux, F., Moulin, C., Bréon, F. M., Maignan, F., Poitou, J., and Tanré, D.: Remote sensing of aerosols over the oceans using MSG/SEVIRI imagery, Ann. Geophys., 23, 3561-3568, doi:10.5194/angeo-23-3561-2005, 2005.

Thomason, L. W., Pitts, M. C., and Winker, D. M.: CALIPSO observations of stratospheric aerosols: a preliminary assessment, Atmos. Chem. Phys., 7, 5283-5290, doi:10.5194/acp-7-5283-2007, 2007.

Vaughan, M. A., Young, S. A., Winker, D. M., Powell, K. A., Omar, A. H., Liu, Z., Hu, Y., and Hostetler, C. A.: Fully automated analysis of space-based lidar data: an overview of the CALIPSO retrieval algorithms and data products, Proc. SPIE Int. Soc. Opt. Eng., 5575, 16-30, doi:10.1117/12.572024, 2004. 